Original article

\title{
Bone formation and growth of climbing perch Anabas testudinieus larvae fed with Zn enriched Artemia nauplii
}

\section{Pembentukan tulang dan pertumbuhan larva ikan betok Anabas testudinieus yang diberi pakan naupli Artemia yang diperkaya dengan $\mathbf{Z n}$}

\author{
Ismarica $^{1}$, Mia Setiawati ${ }^{1 *}$, Dedi Jusadi ${ }^{1}$, Muhammad Agus Suprayudi ${ }^{1}$ \\ 'Department of Aquaculture, Faculty of Fisheries and Marine Sciences, IPB University, Bogor, \\ West Java, Indonesia \\ *Corresponding author: miasetia@apps.ipb.ac.id
}

(Received May 12, 2017; Accepted March 16, 2020)

\begin{abstract}
The aim of this study was to determine the optimum level of Zinc (Zn) enrichment in Artemia sp. nauplii as a live feed to improve bone formation and growth of climbing perch Anabas testudinieus larvae. The study consisted of four different $\mathrm{Zn}$ enrichment levels $(0.0,0.05,0.1$, and $0.15 \mathrm{mg} / \mathrm{mL})$ in Artemia sp. nauplii. The enrichment was performed for 12 hours with the nauplii density of $1 \mathrm{ind} / \mathrm{mL}$. Climbing perch larvae with an average initial length of $1.65 \pm 0.15 \mathrm{~mm}$ were fed four times daily with the enriched nauplii. For the first 5 days, all larvae were fed with rotifer followed by feeding with enriched Artemia nauplii ad libitum. The results showed that the application of Artemia sp. enrichment at $0.1 \mathrm{mg} \mathrm{Zn} / \mathrm{mL}$ influenced the bone formation, increased the growth, and improved the fish survival of climbing perch larvae. Feeding with $0.1 \mathrm{mg} / \mathrm{mL} \mathrm{Zn}$ enriched Artemia nauplii could be recommended as a strategy to improve the bone formation and growth performance of climbing perch larvae.
\end{abstract}

Keywords: Anabas testudineus, Artemia sp., climbing perch, live feed, zinc

\begin{abstract}
ABSTRAK
Penelitian ini bertujuan menentukan dosis optimum pengayaan seng (Zn) pada naupli Artemia sp. terhadap pembentukan tulang dan peningkatan pertumbuhan larva ikan betok. Penelitian dilakukan selama 18 hari dengan empat dosis pengayaan Zn yang berbeda $(0 ; 0,05 ; 0,1 ;$ dan $0,15 \mathrm{mg} / \mathrm{mL})$ pada naupli Artemia. Pengayaan dilakukan selama 12 jam dengan kepadatan naupli $1 \mathrm{ind} / \mathrm{mL}$. Larva ikan betok dengan ukuran panjang awal rata-rata $1.65 \pm$ $0.15 \mathrm{~mm}$ diberi pakan naupli yang diperkaya sebanyak 4 kali sehari. Pada lima hari pertama, semua larva diberi pakan rotifer, diikuti dengan pemberian naupli Artemia yang diperkaya secara ad libitum. Hasil yang diperoleh menunjukkan bahwa pengayaan naupli Artemia sp. dengan $\mathrm{Zn} 0,1 \mathrm{mg} / \mathrm{mL}$ berpengaruh terhadap pembentukan tulang belakang dan dapat meningkatkan pertumbuhan serta meningkatkan kelangsungan hidup larva ikan betok. Pemberian naupli Artemia dengan $\mathrm{Zn}$ sebanyak $0.1 \mathrm{mg} \mathrm{Zn} / \mathrm{mL}$ dapat direkomendasikan untuk perbaikan pembentukan tulang dan pertumbuhan larva ikan betok.
\end{abstract}

Kata kunci: Naupli Artemia sp., ikan betok, pakan alami, seng 


\section{INTRODUCTION}

Climbing perch Anabas testudinieus is a freshwater fish that is potentially cultured due to a high economical value, but having a slow growth (Kohinoor et al., 2012; Morioka et al., 2009). One factor influencing the slow growth is feed. Growth is initially begun with a bone formation. Bone formation happens in two ways, namely through the intra-membrane and endrochondral osification (Boglione et al., 1982). Bone formation needs macro and micro mineral elements. One of important micro minerals in bone formation is zinc $(\mathrm{Zn}) . \mathrm{Zn}$ is a mineral element that is mostly accumulated in bones compared to liver as the main organ of micro mineral preservation (Setiawati et al., 2007) and as a cofactor in bone formation (Yamaguchi, 2010). Kaliky et al. (2019) reported that $\mathrm{Zn}$ also played an important role in the reproduction process of striped catfish.

Commonly, $\mathrm{Zn}$ deficiency in feed can lead to low growth and bone demineralization, especially either on juvenile or adult fish (Baeverfjord et $a l ., 2019)$. On red sea bream larvae, $\mathrm{Zn}$ is also functioned to improve growth and backbone formation (Nguyen et al., 2008). In osteology, $\mathrm{Zn}$ has anabolic effect on the osteogenesis in osteoblast (Seo et al., 2010). Excessive $\mathrm{Zn}$ in feed can decrease the $\mathrm{Ca}$ and $\mathrm{P}$ content in bones and body of giant gouramy fish and increase the Mn content in bones (Setiawati et al., 2007). The addition of $\mathrm{Zn}$ in feed should follow the requirement, thus can balance the other mineral element performances, such as $\mathrm{Ca}, \mathrm{P}$, and $\mathrm{Mg}$ as also important in bone formation and growth (Holt, 2011). Therefore, sufficient $\mathrm{Zn}$ is required for bone formation.

Fish larvae commonly requires $\mathrm{Zn}$ content around 20-30 mg/kg (NRC, 1993). Giant gouramy requires $\mathrm{Zn}$ supplementation of $25-50$ $\mathrm{mg} / \mathrm{kg}$ feed (Setiawati et al., 2007). Fish larvae are commonly and initially fed with live feeds in the form of rotifers and Artemia sp. nauplii. The climbing perch larvae given rotifers on 2 days after hatching $(\mathrm{DAH})(3.027 \mathrm{~mm})$ until $10 \mathrm{DAH}$ $(5.4 \mathrm{~mm})$, while Artemia sp. nauplii are given on 7 DAH (4.2 mm) until $20 \mathrm{DAH}(10.23 \mathrm{~mm})$ (Yulintine, 2012). The Artemia sp. nauplii are small-sized live feed with high nutrient contents (Chahyaningrum et al., 2015), Artemia sp. nauplii and rotifer have a character that can be used as initial feed for larvae based on mouth-opening and slow movement (Yulintine, 2012).

Artemia sp. nauplii have $55.38 \%$ proteins,
$4.42 \%$ lipids, $12.15 \%$ ash, $3.32 \%$ crude fiber, and $24.73 \%$ NFE (Chahyaningrum et al., 2015). However, Artemia sp. nauplii has lower $\mathrm{Zn}$ content than other zooplanktons (Holt, 2011). $\mathrm{Zn}$ content increased on rotifer and Artemia sp. nauplii after enrichment (Matsumoto et al., 2009; Nguyen et al., 2008). Therefore, $\mathrm{Zn}$ needs to be supplemented on rotifer and Artemia sp. through enrichment. Red sea bream larvae improves their growth and normal backbone formation through Zn enrichment on Artemia sp. nauplii (Nguyen $e t$ al., 2008). Thereby, Zn enrichment on Artemia sp. nauplii was importantly conducted in this study to improve growth and bone formation of climbing perch larvae.

\section{MATERIALS AND METHODS}

\section{Container and materials}

The container used was aquarium sized $15 \times 15 \times 20 \mathrm{~cm}^{3}$ as much as 8 pieces for $\mathrm{Zn}$ enrichment on Artemia sp. nauplii and $20 \times 20 \times 30$ $\mathrm{cm}^{3}$ as much as 12 pieces for larval rearing. The climbing perch larvae used were $1.65 \pm 0.15 \mathrm{~mm}$ and stocked around 40 ekor/L, therefore resulting 1700 larvae in total. Artemia sp. nauplii used had $12.18 \%$ proteins, $72.24 \%$ moisture, $3.22 \%$ ash, $0.70 \%$ lipids, $2.02 \%$ crude fiber, and $9.64 \%$ NFE. The $\mathrm{Zn}$ used was in the form of $\mathrm{ZnSO}_{4} .7 \mathrm{H}_{2} \mathrm{O}$.

\section{Artemia sp. cyst hatching}

Artemia sp. cysts were hatched gradually to fulfill the climbing perch larvae live feed availability. Artemia sp. cysts were hatched from 4 days after climbing perch egg hatching. Artemia sp. nauplii were hatched using water filled container with $30 \mathrm{~g} / \mathrm{L}$ salinity. Then, the Artemia sp. cysts were distributed into the hatching container as much as $1 \mathrm{~g}$ and given an aeration for 24 hours. Artemia sp. nauplii were harvested and rinsed with freshwater, then moved into the enrichment container (Setiawati et al.,2013) and taken as much as $2 \mathrm{~g}$ samples of Artemia sp. nauplii for $\mathrm{Zn}$ mineral analysis and 10 $\mathrm{g}$ for proximate analysis.

\section{Zn enrichment on Artemia sp. nauplii}

The Zn enrichment on Artemia sp. nauplii was performed by following the nutrient enrichment method for live feed (Rahardja et al., 2009). The enrichment container was filled with $200 \mathrm{~mL}$ freshwater and $6 \mathrm{~g}$ salt. The hatched Artemia sp. nauplii were stocked into the available container with 1 nauplius/mL density (Setiawati et al., 2013). 
Then, different dozes of $\mathrm{Zn}(0.0,0.05,0.1$, and $0.15 \mathrm{mg} / \mathrm{L}$ ) were added and dissolved with water into the enrichment container. The Artemia sp. nauplii were harvested after 12 hours (Matsumoto et al., 2009) and rinsed with freshwater, then directly given to the climbing perch larvae. The enriched Artemia sp. nauplii were taken $2 \mathrm{~g}$ from each treatment for $\mathrm{Zn}$ mineral analysis and $10 \mathrm{~g}$ from each treatment for proximate analysis.

\section{Climbing perch larval rearing}

The newly hatched climbing perch larvae were reared on the prepared aquaria with the stocking density of each aquarium was 120 larvae (40 larvae/L) for 18 days. before stocked, larvae were acclimatized for 15 minutes in the aquarium. Larvae were initially fed on 2 days after hatching (when the egg yolk was fully absorbed) until 5 days after hatching by giving $5 \mathrm{ind} / \mathrm{ml}$ rotifers with 4 times daily. Climbing perch larvae were given $\mathrm{Zn}$-enriched Artemia sp. nauplii ad libitum with 4 times daily. The water quality during the larval rearing period was controlled at 6.5-7.0 $\mathrm{mg} / \mathrm{L}$ dissolved oxygen, $\mathrm{pH} 6.9-7.0$, and $28-30^{\circ} \mathrm{C}$ temperature. Water quality maintenance was performed by syphonization every morning before feeding and 50\% water exchange. After the climbing perch larvae were harvested, larvae were taken 20 larvae from each replication as absolute length growth samples and 3 larvae from each treatment for bone staining using Alizarin red and Alcian blue method.

\section{Parameters}

Parameters obtained were; Artemia sp. nauplii proximate analysis, $\mathrm{Zn}$ mineral analysis on Artemia sp. nauplii and rotifer, $\mathrm{Zn}, \mathrm{P}, \mathrm{Ca}$, and $\mathrm{Mg}$ mineral analysis on fish larvae, survival rate, absolute length growth, and backbone formation.

\section{RESULT AND DISCUSSION}

\section{Hasil}

\section{Artemia sp. nauplii proximate}

The proximate analysis result showed that $\mathrm{Zn}$ enriched Artemia sp. nauplii had a different proximate composition (Table 1 ). Table 2 showed the mineral analysis result of $\mathrm{Zn}$ on rotifers and Artemia sp. nauplii, besides mineral analysis of $\mathrm{Zn}, \mathrm{P}, \mathrm{Ca}$, and $\mathrm{Mg}$ in fish larvae given nauplii enriched with different $\mathrm{Zn}$. The $\mathrm{Zn}$ content on Artemia sp. nauplii enriched with $\mathrm{Zn}$ was higher

Table 1. The proximate composition of Artemia sp. nauplii enriched with different $\mathrm{Zn}(\mathrm{mg} / \mathrm{mL})$.

\begin{tabular}{lcccc}
\hline \multirow{2}{*}{$\begin{array}{c}\text { Nutrient content } \\
\text { (\% dry weight })\end{array}$} & 0 & 0.05 & 0.1 & 0.15 \\
\cline { 2 - 5 } & 72.24 & 71.98 & 72.21 & 72.32 \\
Moisture & 3.22 & 3.24 & 3.23 & 3.19 \\
Ash & 12.18 & 12.2 & 12.19 & 12.15 \\
Protein & 0.7 & 0.75 & 0.73 & 0.69 \\
Lipid & 2.02 & 2.08 & 2.03 & 2 \\
Crude fiber & 9.64 & 9.75 & 9.61 & 9.65 \\
NFE (Nitrogen free extract) & & &
\end{tabular}

Table 2. The mineral concentration of $\mathrm{Zn}$ on Artemia sp. and mineral composition of $\mathrm{Zn}, \mathrm{P}, \mathrm{Ca}$, and $\mathrm{Mg}$ on fish larvae fed Artemia nauplii enriched with different $\mathrm{Zn}$ concentrations

\begin{tabular}{ccccc}
\hline \multirow{2}{*}{ Mineral content $(\mathrm{mg} / \mathrm{kg})$} & 0 & \multicolumn{4}{c}{ Zn enrichment concentration $(\mathrm{mg} / \mathrm{mL})$} \\
\cline { 2 - 5 } & \multicolumn{5}{c}{ Artemia sp. nauplii } \\
\hline $\mathrm{Zn}$ & $20.05 \pm 0.11$ & $24 \pm 0.10$ & $25.47 \pm 0.15$ & $26.19 \pm 0.13$ \\
\hline \multicolumn{5}{c}{ Climbing perch larvae } \\
$\mathrm{Zn}$ & $35.12 \pm 0.29^{\mathrm{a}}$ & $46.53 \pm 0.19^{\mathrm{b}}$ & $47.65 \pm 0.05^{\mathrm{c}}$ & $48.58 \pm 0.14^{\mathrm{d}}$ \\
$\mathrm{P}$ & $3160 \pm 1^{\mathrm{a}}$ & $3286 \pm 11^{\mathrm{b}}$ & $3513 \pm 41^{\mathrm{c}}$ & $3728 \pm 20^{\mathrm{d}}$ \\
$\mathrm{Ca}$ & $5170 \pm 1^{\mathrm{a}}$ & $5373 \pm 7^{\mathrm{b}}$ & $5473 \pm 4^{\mathrm{c}}$ & $5608 \pm 6^{\mathrm{d}}$ \\
$\mathrm{Mg}$ & $209 \pm 1^{\mathrm{a}}$ & $214 \pm 1^{\mathrm{b}}$ & $221 \pm 1^{\mathrm{c}}$ & $237 \pm 0^{\mathrm{d}}$ \\
\hline
\end{tabular}

Note: $\mathrm{Zn}=$ Zinc, $\mathrm{P}=$ phosphorous, $\mathrm{Ca}=$ calcium, and $\mathrm{Mg}=$ magnesium. Different letters behind the average values ( \pm standard deviation) on the same line show a significant difference $(\mathrm{P}<0.05)$ 

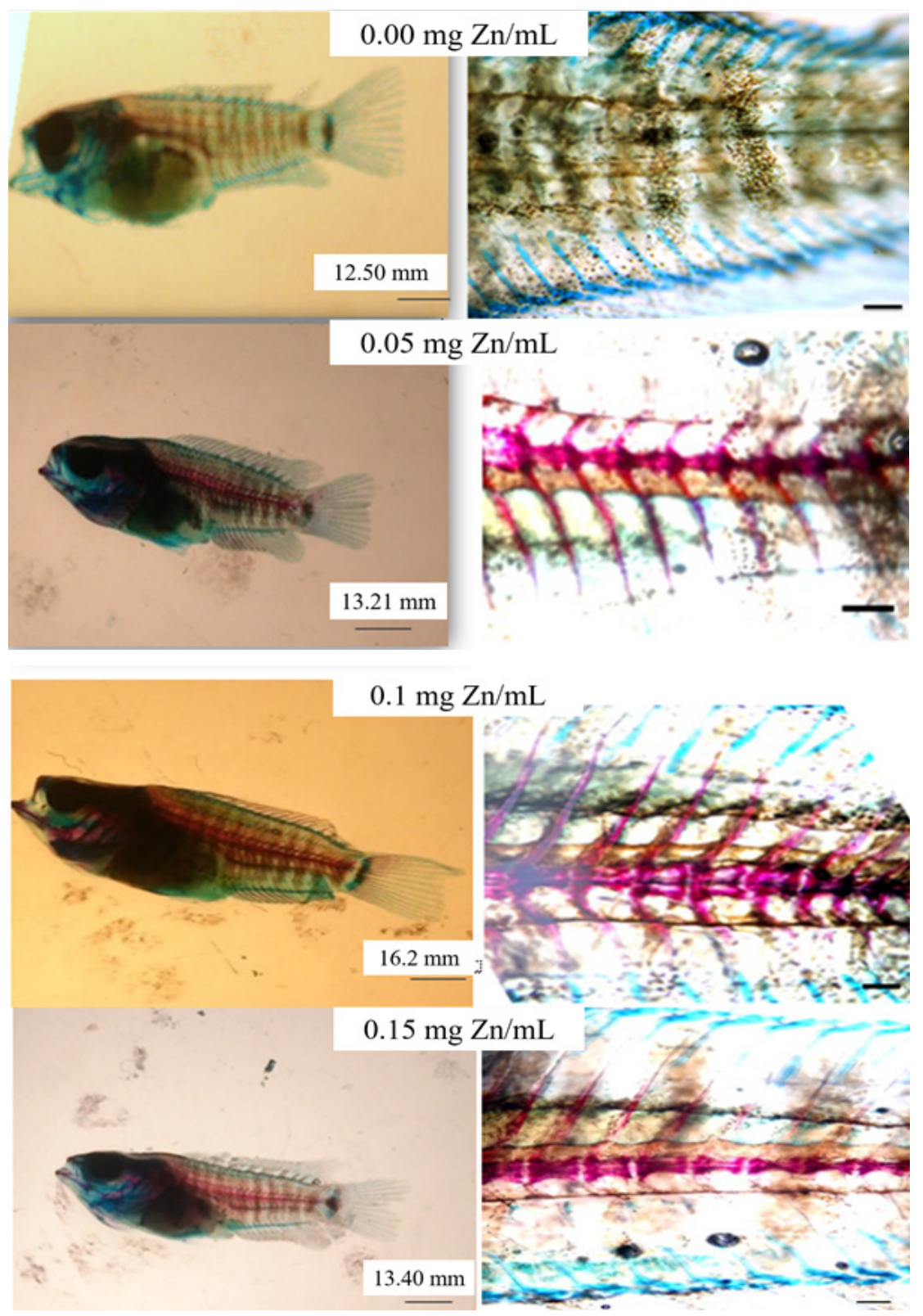

Figure 1. The micrograph of climbing perch larvae backbones after fed Artemia sp. nauplii enriched with different Zn concentrations on 18 days after hatching.

Table 3. Final length $(\mathrm{mm})$, absolute length growth $(\mathrm{mm})$, and survival rate $(\%)$ of climbing perch larvae fed Artemia nauplii enriched with different $\mathrm{Zn}$ dozes after 18 days of rearing period.

\begin{tabular}{lcccc}
\hline \multirow{2}{*}{ Parameter } & \multicolumn{4}{c}{ Zn enrichment concentration given to Artemia sp. nauplii $(\mathrm{mg} / \mathrm{mL})$} \\
\cline { 2 - 5 } & 0 & 0.05 & 0.1 & 0.15 \\
\hline $\mathrm{Lt}(\mathrm{mm})$ & $12.62 \pm 0.25^{\mathrm{a}}$ & $13.47 \pm 1.03^{\mathrm{ab}}$ & $15.03 \pm 1.11^{\mathrm{b}}$ & $14.07 \pm 0.95^{\mathrm{ab}}$ \\
$\mathrm{ALG}(\mathrm{mm})$ & $10.96 \pm 0.246^{\mathrm{a}}$ & $11.81 \pm 1.026^{\mathrm{ab}}$ & $13.38 \pm 1.10^{\mathrm{b}}$ & $12.41 \pm 0.95^{\mathrm{ab}}$ \\
$\mathrm{SR}(\%)$ & $45.55 \pm 7.47^{\mathrm{a}}$ & $48.61 \pm 3.46^{\mathrm{a}}$ & $64.72 \pm 7.51^{\mathrm{b}}$ & $70.55 \pm 11.70^{\mathrm{b}}$ \\
\hline Note: SR $=$ Survival rate, $\mathrm{PPM}=$ absolute length growth, $\mathrm{Pt}=$ final length. Different letters behind the average \\
values $( \pm$ standard deviation) on the same line show a significant difference $(\mathrm{P}<0.05)$.
\end{tabular}


than without $\mathrm{Zn}$ enrichment. Hasil analisis mineral larva ikan menunjukkan bahwa semakin tinggi konsentrasi pengayaan Znmaka semakin tinggi kandungan mineral $(\mathrm{Zn}, \mathrm{P}, \mathrm{Ca}$, dan $\mathrm{Mg}$ ) pada larva ikan betok. The mineral analysis on fish larvae indicated that the higher $\mathrm{Zn}$ enrichment concentration given, the higher mineral contents ( $\mathrm{Zn}, \mathrm{P}, \mathrm{Ca}$, and $\mathrm{Mg}$ ) obtained.

\section{Backbone formation on climbing perch larvae}

Artemia sp. nauplii enriched with 0.05, 0.1, and $0.15 \mathrm{mg} / \mathrm{mL} \mathrm{Zn}$ influenced the climbing perch backbone formation (Figure 1). Based on the observation of climbing perch larvae backbone formation, the enriched Artemia sp. nauplii given with $0.1 \mathrm{mg} / \mathrm{mL} \mathrm{Zn}$ obtained a red colored hard bone phase condition. Meanwhile, Artemia sp. nauplii without $\mathrm{Zn}$ enrichment only obtained a transition phase between cartilaginous to hard bone shown from the transition of transparent blue to red colored bones.

\section{Absolute length growth and survival rate}

The climbing perch larva fed Artemia sp. nauplii enriched with $0.1 \mathrm{mg} / \mathrm{mL} \mathrm{Zn}$ had a higher absolute length growth value than control $(\mathrm{P}<0.05)$ (Table 3). The highest survival rate of climbing perch larvae was obtained from larvae fed Artemia sp. nauplii enriched with 0.1 and 0.15 $\mathrm{mg} / \mathrm{mL} \mathrm{Zn} \mathrm{compared} \mathrm{to} \mathrm{other} \mathrm{treatments.}$

\section{Discussion}

The Zn content on Artemia sp. nauplii enriched with $\mathrm{Zn}$ increased along with the increased concentration of $\mathrm{Zn}$ in the enrichment solution. This followed the previous results of Nguyen et al. (2008) and Matsumoto et al. (2009). The increased $\mathrm{Zn}$ content was caused as Artemia sp. nauplii could absorb available $\mathrm{Zn}$ better in the enrichment container. This study result showed that Artemia nauplii enriched with $\mathrm{Zn}$ increased the $\mathrm{Zn}$ concentration of larval body. This condition followed the result of Eid and Ghonim (1994), who stated that the increased Zn content in Oreochromis niloticus fish feed could also increase the $\mathrm{Zn}$ content in bones and growth. The increased mineral contents of $\mathrm{P}, \mathrm{Ca}$, and $\mathrm{Mg}$ was due to the synergetic relationship with $\mathrm{Zn}$ mineral. According to Setiawati et al. (2007), excessive Zn content in feed could decline $\mathrm{P}$ and $\mathrm{Ca}$ content in bones as the analysis result on giant gourami indicated that $\mathrm{Zn}$ in feed tended to increase the body $\mathrm{Zn}$ content, therefore accumulated in the body as one of which was in the bone tissues. The increased $\mathrm{Zn}$ mineral in climbing perch larval body influenced the backbone formation, besides survival rate and growth of climbing perch larvae. The same result was reported on gilthead seabream that showed increased growth, bone mineralization, and decreased abnormality level, when given $\mathrm{Se}, \mathrm{Mn}$, and $\mathrm{Zn}$ supplemented feed (Izquierdo et al., 2016).

The result indicated that Artemia sp. nauplii enriched with $0.1 \mathrm{mg} / \mathrm{mL} \mathrm{Zn}$ could accelerate the backbone formation marked by the increased length growth of climbing perch larvae. $\mathrm{Zn}$ is known to induce the cell differentiation, cell proliferation, and mineralization in osteoblast (bone tissue), as well as improving the insulin-like growth factor I (IGF-I) and transforming growth factor $\beta 1$ (TGF $\beta 1)$ production in osteoblastic cells (Yamaguchi, 2010). The larval backbone formation is closely related to feed utilization effectivity and nutrient content completeness in feed consumed, therefore will be expressed on the morphological appearance (Aslianti et al., 2014). Bone formation that is still in the cartilaginous phase affects on the low survival rate and slow growth. Larvae on the cartilaginous phase are at high risk to be dead during the rearing period.

This study result showed that climbing perch larval growth was commonly better than the previous study. This condition happened as only taking 18 days to reach more than $12 \mathrm{~mm}$ length, which was faster than the study of Yulintine (2012) that required more than 20 days. The $\mathrm{Zn}$ enriched Artemia nauplii given produced better growth and survival rate than control. This condition indicated that $\mathrm{Zn}$ had a very important role in fish larval growth. A study on carp showed that the supplementation of $\mathrm{Zn}$ in feed could improve protein concentration in blood and intestine (Chupani et al., 2017; 2018), while on giant freshwater prawn, the supplementation of $\mathrm{Zn}$ was reported to improve growth, survival rate, and immunity (Muralisankar et al., 2014; 2015). Fish feed with $20 \mathrm{mg} / \mathrm{kg} \mathrm{Zn}$ produced the highest weight and SGR and was significantly different among other treatments $(\mathrm{P}<0.05)$ (Mondal et al., 2020).

The survival rate value of climbing perch larvae on Artemia sp. nauplii enriched with 0.1 $\mathrm{mg} / \mathrm{mL} \mathrm{Zn}$ treatment was $64.72 \%$, higher than the survival rate of climbing perch reported by Morioka et al. (2009) with $20 \%$ and Bugar et al. (2013) with 18-31\%. Artemia sp. nauplii enrichment with $\mathrm{Zn}$ was suspected to induce the climbing perch larval resistance. $\mathrm{Zn}$ also had an 
important role on the growth of rohu fish Labeo rohita. SGR of rohu fish was reported to improve along the increased doze of $\mathrm{Zn}$ until $42 \mathrm{mg} / \mathrm{kg}$ (Akram et al., 2019). The increased survival rate of climbing perch larvae was due to the normal condition occurred to maintain the movement space and utilize the feed maximally for sustaining the survival rate (Bugar et al., 2013). Moreover, the increased survival rate of climbing perch larvae was also due to the sufficient live feed given as based on the larval mouth-opening and number of feed given that could create a normal condition for larval movement space during the rearing period (Suriansyah, 2012).

\section{CONCLUSION}

The Artemia sp. nauplii given with $0.1 \mathrm{mg} / \mathrm{mL}$ $\mathrm{Zn}$ enrichment could increase the larval backbone formation and growth rate, as well as survival rate of climbing perch larvae.

\section{REFERENCES}

Akram Z, Fatima M, Shah SZH, Afzal M, Hussain SM, Hussain M. 2019. Dietary zinc requirement of Labeo rohita juveniles fed practical diets. Journal of Applied Animal Research 47: 223-229.

Aslianti T, Nasukha A, Setyadi I. 2014. Vertebral development and protease activity of larval milkfish, Chanos chanos Forsskal in different rearing media. Jurnal Ilmu dan Teknologi Kelautan Tropis 6: 87-100.

Baeverfjord G, Prabhu PAJ, Fjelldal PG, Albrektsen S, Hatlen B, Denstadli V, Ytteborg E, Takle H, Lock EJ, Berntssen MHG, Lundebye AK, Åsgaård T, Waagbø R. 2019. Mineral nutrition and bone health in salmonids. Reviews in Aquaculture 11: 740-765.

Boglione C, Gavaia P, Koumoundouros G, Gisbert E, Moren M, Fontagné S, Witten PE. 2013. Skeletal anomalies in reared European fish larvae and juveniles. Part 1: normal and anomalous skeletogenic processes. Reviews in Aquaculture 5: 99-120.

Bugar H, Bungas K, Monalisa SS, Christiana I. 2013.Spawning and larvae handling of climbing perch Anabas testudineus (Bloch) in peat water. Jurnal Ilmu Hewani Tropika 2: 90-96.

Chahyaningrum RN, Subandiyono, Herawati VE. 2015. The utilization rate of frozen Artemia sp., preserved Artemia sp., and fresh silk worms for the growth, and survivors of "Sangkuriang" catfish Clarias gariepinus larvae. Aquaculture Management and Technology 4: 18-25.

Chupani L, Zusková E, Niksirat H, Panáček A, Lünsmann V, Haange S-B, von Bergen $M$, Jehmlich N. 2017. Effects of chronic dietary exposure of zinc oxide nanoparticles on the serum protein profile of juvenile common carp Cyprinus carpio (L.). Science of the Total Environment 579: 1504-1511.

Chupani L, Niksirat H, Lünsmann V, Haange $\mathrm{SB}$, von Bergen $\mathrm{M}$, Jehmlich, Zusková E. 2018. Insight into the modulation of intestinal proteome of juvenile common carp Cyprinus carpio (L.) after dietary exposure to $\mathrm{ZnO}$ nanoparticles. Science of The Total Environment 613-614: 62-71.

Eid AE, Ghonim SI. 1994. Dietary zinc requirement of fingerling Oreochromis niloticus. Aquaculture 119: 259-264.

Holt GJ. 2011. Larval Fish Nutrition. Bibliographical references and index. ISBN 978-0-8138-1792-7.

Izquierdo MS, Ghrab W, Roo J, Hamre K, Hernández-Cruz CM, Bernardini G, Terova G, Saleh R. 2017. Organic, inorganic and nanoparticles of $\mathrm{Se}, \mathrm{Zn}$ and $\mathrm{Mn}$ in early weaning diets for gilthead seabream Sparus aurata (Linnaeus, 1758). Aquaculture Research 48:1-16.

Kaliky NAPSB, Setiawati M, Carman O, Utomo NBP, Rahman. 2019. Effect of zinc (Zn) supplementation on quality and quantity of striped catfish Pangasianodon hypophthalmus sperm. Jurnal Akuakultur Indonesia 18: 4653.

Kohinoor AHM, Islam MS, Jahan DA, Khan MM, Hussain MG. 2012. Growth and production performances of crossbred climbing perch koi, Anabas testudineus in Bangladesh. International Journal of Agricultural Research, Innovation and Technology 2: 19-25.

Matsumoto S, Satoh S, Kotani T, Fushimi H. 2009. Examination of a practical method for zinc enrichment of euryhaline rotifers Brachionus plicatilis. Aquaculture 286: 113-120.

Morioka S, Ito S, Kitamura S, Vongvichith B. 2009. Growth and morphological development of laboratory-reared larval and juvenile climbing perch Anabas testudineus. Ichthyological Research 56: 162-171.

Mondal AH, Behera T, Swain P, Das R, Sahoo SN, Mishra SS, Das J, Ghosh K. 2020. Nano zinc vis-à-vis inorganic Zinc as feed additives: 
Effects on growth, activity of hepatic enzymes and non-specific immunity in rohu, Labeo rohita (Hamilton) fingerlings. Aquaculture Nutrition 26: 1-12.

Muralisankar T, Bhavan PS, Radhakrishnan S, Seenivasan C, Manickam N, Srinivasan V.2014. Dietary supplementation of zinc nanoparticles and its influence on biology, physiology and immune responses of the freshwater prawn, Macrobrachium rosenbergii. Biological Trace Element Research 160: 56-66.

Muralisankar T, Bhavan PS, Radhakrishnan S, Seenivasan C, Srinivasan V, Santhanam P. 2015. Effects of dietary zinc on the growth, digestive enzyme activities, muscle biochemical compositions, and antioxidant status of the giant freshwater prawn Macrobrachium rosenbergii. Aquaculture 448:98-104.

National Research Council [NRC]. 1993. Nutrient Requirements of Fish. National Academy Press, Washington, DC. pp. 114.

Nguyen VT, Satoh S, Haga Y, Fushimi H, Kotani T. 2008. Effect of zinc and manganese supplementation in Artemia on growth and vertebral deformity in red sea bream Pagrus majorlarvae. Aquaculture 285:184-192.

Rahardja BS, Satyantini WH, Mufidah NBW. 2009. Enrichment of Daphnia spp. with viterna to survival and growth of Arican catfish Clarias gariepinus larvae. Jurnal Ilmiah Perikanan dan Kelautan 1: 59-65.

Seo HJ, Cho YE, Kim T, Shin HI, Kwun IS. 2010. Zinc may increase bone formation through stimulating cell proliferation, alkaline phosphatase activity and collagen synthesis in osteoblastic MC3T3-E1 cells. Nutrition Research and Practice 4: 356-361.

Setiawati M, Putri D, Jusadi D. 2013. Survival and growth of catfish Pangasionodon sp. larvae fed on vitamin C-enriched Artemia. Jurnal Akuakultur Indonesia 12: 137-144.

Setiawati M, Azwar NR, Mokoginta I, Affandi R. 2007. Dietary zinc requirement of young giant gouramy Osphronemus gouramy, Lac. JurnalAkuakultur Indonesia 6: 161-169.

Suriansyah. 2012. Survival rate of fry swim climbing perch Anabas testudineus (Bloch) at irrigate peat with different percentage of natural food. Jurnal Ilmu Hewan Tropikal 1: 47-52.

Yamaguchi M. 2010. Role of nutritional zinc in the prevention of osteoporosis. Molecular and Cellular Biochemustry 338: 241-254.

Yulintine. 2012. Effort of survival rate improvement of climbing perch Anabas testudineus Bloch larvae through study on digestive system ontogeny, HUFA biosynthesis ability and essential fatty acid enrichment. [Dissertation]. Faculty of Fisheries and Marine Sciences, IPB University. 